\title{
Water-Sediment Partition of Polycyclic Aromatic Hydrocarbons (PAHs) in Nansi Lake
}

\author{
Guizhai Zhang, Youjiang Diao* \\ School of Environment Science and Engineering, Shandong Agriculture and Engineering University, Jinan, Shandong, 251100, P. R. \\ China
}

\begin{abstract}
Based on field data of polycyclic aromatic hydrocarbons (PAHs) in water and sediment in Nansi Lake. The concentrations and the partitioning characteristic of PAHs in the water and sediment were studied. The lgKd of high molecular weight PAHs were higher than the low molecular weight PAHs. The most of PAHs Kd values were negligible correlated with TOC, soluble salt, clay and $\mathrm{pH}$ of the sediment in Nansi Lake.
\end{abstract}

\section{Introduction}

Polycyclic aromatic hydrocarbons (PAHs), containing two or more benzene rings, are widely distributed in the environment, for heir hydrophobicity, strong persistence and long-range transportation potential [1]. PAHs usually exist in the form of free, DOM binding, SPM binding and sediment combination in the aquatic environment. Investigation of the distribution of PAHs in an aquatic environment is great significance for strategy designing of pollution control. Partitioning in the two phases plays an important role in their behavior in the environment. The distribution of PAHs was mainly influenced by the characters of sediment (organic carbon content, particle composition) and environmental conditions ( $\mathrm{pH}$ value, soluble salt content and so on), besides the physicochemical characters of PAHs and environmental conditions (temperature, precipitation) [2]. It is necessary

\section{Materials and methods}

\subsection{Site location and sample collection}

The locations of the sampling sites are shown in the paper by Zhang [1]. Water and surface sediment collected in May 2011.

\subsection{Extraction procedure and chemical analysis}

The Chemical reagents, extraction procedure, chemical analysis and Quality assurance are found in the literature [1].

\subsection{The analysis of physicochemical character in surface sediment}

to study the partitioning of PAHs in different aquatic environments, for the different partitioning behaviors of PAHs in different study areas.

Nansi Lake is the largest lake in Shandong province, the northern area of China, including Nanyang Lake, Dushan Lake, Zhaoyang Lake and Weishan Lake. It is an imporant buffer lake of the South-to-North Water Diversion Project (east route). Its water quality relates to the whole water quality conditions of South-to-North Water Diversion Project (east route) [3]. Some studies [1, $4,5]$ assessed the PAHs residues in water, sediment and aquatic organisms of Nansi Lake. However, there is little information on water-sediment Partition of Polycyclic Aromatic Hydrocarbons (PAHs) in Nasi lake.

The objectives of this research are to survey concentrations of PAHs in the water and sediment, to evaluate water-sediment partitioning coefficient $\left(\mathrm{K}_{\mathrm{d}}\right)$ of PAHs, and to assess the relationship of characteristics in sediments with $K_{d}$ of PAHs in the Nansi Lake.

The methods total organic carbon (TOC), mechanical analyses, soluble salt contents and $\mathrm{pH}$ of sediments were following the method of Zhang [3]. Statistical analysis software Spss16.0 was used in this study.

\section{Results and discussion}

\subsection{Concentrations of PAHs in the water and sediment}

The concentrations of PAHs in water and sediment samples are shown in Table 1. The results of PAHs in water and sediment samples came from the report by zhang [1]. The concentrations of total PAHs ranged from $27.52 \mathrm{ng} / \mathrm{L}$ to $55.06 \mathrm{ng} / \mathrm{L}$ in water, with the average value of $34.38 \pm 10.34 \mathrm{ng} / \mathrm{L}$. The low molecular weight (2-3 rings) PAHs were dominant PAHs compounds, accounting for approximately $83 \%$ of total PAHs in 
water.

The concentrations of total PAHs ranged from 80.3 $\mathrm{ng} / \mathrm{g} \mathrm{dw}$ to $639.47 \mathrm{ng} / \mathrm{g} \mathrm{dw}$ in sediment, with the average value of $225.18 \pm 206 \mathrm{ng} / \mathrm{g} \mathrm{dw}$. The high molecular weight
(4-6 rings) PAHs were major compounds in sediment compared in water, accounting for approximately $56 \%$ of total PAHs in sediment. Those results were consistent with previous studies $[6,7]$.

Table 1 The concentrations of PAHs in water and sediment samples

\begin{tabular}{ccc}
\hline & Water $(\mathrm{n}=6)$ & sediment $(\mathrm{n}=6)$ \\
\cline { 2 - 3 } PAHs & mean \pm SD & mean \pm SD \\
\hline Acy & $1.19 \pm 0.46$ & $1.92 \pm 0.7$ \\
Fl & $5.98 \pm 0.74$ & $6.96 \pm 2.72$ \\
Ph & $5.92 \pm 2.25$ & $19.78 \pm 7.57$ \\
An & $15.07 \pm 5.75$ & $53.25 \pm 28.68$ \\
Flu & $1.13 \pm 0.53$ & $6.99 \pm 4.35$ \\
Pyr & $2.14 \pm 0.34$ & $30.51 \pm 33.11$ \\
Chr & $2.29 \pm 0.36$ & $27.74 \pm 25.7$ \\
BbF & $1.03 \pm 0.54$ & $13.22 \pm 16.75$ \\
BkF & $0.25 \pm 0.08$ & $15.75 \pm 17.95$ \\
BaA & $0.077 \pm 0.02$ & nd \\
BaP & $0.21 \pm 0.17$ & $12.41 \pm 17.46$ \\
InP & $0.052 \pm 0.02$ & $12.23 \pm 18.77$ \\
DBA & $0.038 \pm 0.01$ & $12.33 \pm 16.05$ \\
BghiP & $0.025 \pm 0.01$ & $2.82 \pm 3.88$ \\
LMW (2-3 rings PAHs $)$ & $0.045 \pm 0.02$ & $14.62 \pm 16.68$ \\
HMW (4-6 rings PAHs $)$ & $30.44 \pm 9.68$ & $114.06 \pm 74.58$ \\
PAHs & $3.94 \pm 0.97$ & $111.12 \pm 132.83$ \\
\hline & $34.38 \pm 10.34$ & $225.18 \pm 206$ \\
\hline
\end{tabular}

nd not detected

\subsection{Water-Sediment partitioning of PAHs in the Nansi Lake}

The partitioning coefficient $\left(\mathrm{K}_{\mathrm{d}}\right)$ of PAHs between sediment and water was calculated by the following formula: $\mathrm{K}_{\mathrm{d}}=\mathrm{C}_{\mathrm{s}} / \mathrm{C}_{\mathrm{w}}$ [8]. where $\mathrm{C}_{\mathrm{s}}$ and $\mathrm{C}_{\mathrm{w}}$ represent PAHs concentration in sediment $(\mathrm{ng} / \mathrm{g} \mathrm{dw})$ and water $(\mathrm{ng} / \mathrm{L})$ samples, respectively. The $\operatorname{lgK}_{d}(\mathrm{~L} / \mathrm{kg})$ values at sediment-water interface from Nansi Lake are shown in table 2 .

In this study, The Flu had higher $\operatorname{lgK}_{d}$ value among the low molecular weight (2-3 rings) PAHs. The $\lg \mathrm{K}_{d}$ average values of the high molecular weight (4-6 rings)
PAHs were in the range of 0.97-2.12 except the not detected compounds. The $\lg \mathrm{K}_{\mathrm{d}}$ values of $\mathrm{InP}, \mathrm{BaA}, \mathrm{BaP}$, $\mathrm{BbF}$ were higher than the other high molecular weight PAHs. The InP, BaA, BaP and BbF were carcinogenic compounds, their average values of $\lg \mathrm{K}_{\mathrm{d}}$ in this study were lower than those in report [9].

This result shows that the low molecular weight PAHs are main compounds in water and sediment, but, the $\lg \mathrm{K}_{\mathrm{d}}$ values of high molecular weight PAHs were higher than the low molecular weight PAHs. This is mainly because the water solubility of PAHs is lower and the lipids are stronger with the number of benzene rings increasing. The higher octanol-water distribution coefficient of PAHs is stronger adsorbed in sediment.

Table $2 \mathrm{Lg} \mathrm{Kd}(\mathrm{L} / \mathrm{Kg})$ at sediment-water interface from Nansi Lake

\begin{tabular}{ccccccc}
\hline PAHs & S1 & S2 & S3 & S4 & S5 & S6 \\
\hline Acy & 0.22 & 0.02 & 0.08 & 0.36 & 0.15 & 0.39 \\
Ace & 0.18 & 0.08 & 0.17 & 0.33 & 0.1 & 0 \\
F1 & 0.64 & 0.28 & 0.5 & 0.24 & 0.64 & 0.81 \\
Ph & 0.47 & 0.29 & 0.55 & 0.29 & 0.69 & 0.86 \\
An & 0.76 & 0.55 & 0.74 & 0.38 & 1.01 & 1.13 \\
Flu & 0.97 & 0.96 & 0 & 0.46 & 0.96 & 1.61 \\
Pyr & 1.05 & 1.04 & 0.78 & 0.61 & 0.92 & 1.45
\end{tabular}




\begin{tabular}{ccccccc} 
Chr & 0.97 & 0.6 & 1.14 & 0.78 & 0.77 & 1.53 \\
$\mathrm{BbF}$ & 1.59 & 1.51 & 1.63 & 1.35 & 1.46 & 2.35 \\
$\mathrm{BkF}$ & $\mathrm{nd}$ & $\mathrm{nd}$ & $\mathrm{nd}$ & $\mathrm{nd}$ & $\mathrm{nd}$ & $\mathrm{nd}$ \\
$\mathrm{BaA}$ & 1.51 & 1.1 & 1.83 & 1.82 & 1.7 & 2.18 \\
$\mathrm{BaP}$ & 1.92 & 1.8 & 2.24 & 1.75 & 1.9 & 3.1 \\
$\mathrm{InP}$ & 2.27 & 2.23 & 2.2 & 2.03 & 2.12 & $\mathrm{nd}$ \\
$\mathrm{DBA}$ & $\mathrm{nd}$ & 1.91 & $\mathrm{nd}$ & $\mathrm{nd}$ & $\mathrm{nd}$ & 2.55 \\
$\mathrm{BghiP}$ & $\mathrm{nd}$ & 2.4 & 2.57 & 2.03 & 1.98 & $\mathrm{nd}$ \\
LMW & 0.53 & 0.35 & 0.4 & 0.22 & 0.63 & 1.02 \\
$\mathrm{HMW}$ & 1.28 & 1.16 & 1.29 & 0.96 & 1.15 & 1.9 \\
$\sum$ PAHs & 0.7 & 0.54 & 0.65 & 0.37 & 0.75 & 1.34 \\
\hline
\end{tabular}

nd not detected

Table 3 The characteristics of samples sites in the Nansi Lake.

\begin{tabular}{ccccccc}
\hline $\begin{array}{c}\text { Sampling } \\
\text { sites }\end{array}$ & $\mathrm{pH}$ & TOC $(\%)$ & $\begin{array}{c}\text { Soluble } \\
\text { salt }(\mathrm{g} / \mathrm{kg})\end{array}$ & Clay(\%) & Silt (\%) & Sand(\%) \\
\hline S1 & 9.05 & 4.29 & 3.06 & 4.2 & 58.0 & 37.8 \\
S2 & 9.58 & 6.06 & 4.66 & 4.9 & 70.3 & 24.8 \\
S3 & 8.22 & 2.61 & 1.80 & 4.3 & 67.7 & 28.0 \\
S4 & 8.38 & 5.19 & 4.26 & 3.6 & 52.9 & 43.5 \\
S5 & 7.67 & 1.20 & 1.40 & 3.7 & 55.9 & 40.6 \\
S6 & 7.60 & 1.73 & 3.34 & 3.4 & 72.1 & 24.5 \\
\hline
\end{tabular}

Table 4 shows that the $\mathrm{K}_{\mathrm{d}}$ value of $\mathrm{InP}$ is positively

\subsection{The characteristics of surface sediment in the Nansi Lake}

The results of characteristics of surface sediment are showed in Table 3. The value of TOC, soluble salt and $\mathrm{pH}$ ranged from $1.20-6.06 \%, 1.40-4.66 \mathrm{~g} / \mathrm{kg}$ and $7.60-9.58$, respectively. Concentrations of clay was lower than silt and sand concentrations.

\subsection{The relationship of characteristics in sediments with Kd of PAHs}

correlated with TOC; the $\mathrm{K}_{\mathrm{d}}$ value of Ace is positively correlated with TOC, soluble salt and $\mathrm{pH}$; the $\mathrm{K}_{\mathrm{d}}$ value of BghiP is positively correlated with soluble salt and Clay. Previous reports found that organic carbon, soluble salt, Clay, $\mathrm{pH}$ in sediment could affect the partitioning of PAHs between sediment and water. In the present study, the analysis results indicate that TOC, soluble salt, clay and $\mathrm{pH}$ of the sediment was negligible correlated with the $K_{d}$, which was consistent with Zhang [10]. Further research is needed.

Table 4 Correlation of characteristics in sediments with Kd of PAHs in Nansi Lake

\begin{tabular}{ccccc}
\hline & $\mathrm{pH}$ & $\mathrm{TOC}$ & soluble salt & Clay \\
\hline Acy & -0.512 & 0.231 & -0.296 & -0.861 \\
Ace & 0.199 & 0.824 & 0.524 & -0.055 \\
$\mathrm{Fl}$ & -0.594 & -0.621 & -0.89 & -0.476 \\
$\mathrm{Ph}$ & -0.802 & -0.781 & -0.922 & -0.593 \\
$\mathrm{An}$ & -0.661 & -0.833 & -0.929 & -0.439 \\
$\mathrm{Flu}$ & -0.15 & -0.369 & -0.471 & -0.305 \\
$\mathrm{Pyr}$ & -0.155 & -0.52 & -0.482 & -0.135 \\
$\mathrm{Chr}$ & -0.591 & -0.339 & -0.53 & -0.519 \\
$\mathrm{BbF}$ & -0.443 & -0.473 & -0.498 & -0.389 \\
$\mathrm{BaA}$ & -0.881 & -0.247 & -0.588 & -0.866 \\
$\mathrm{BaP}$ & -0.577 & -0.513 & -0.541 & -0.469 \\
$\mathrm{InP}$ & 0.562 & 0.399 & 0.487 & 0.603 \\
$\mathrm{DBA}$ & 0.031 & -0.36 & -0.036 & 0.035 \\
$\mathrm{BghiP}$ & 0.16 & -0.011 & 0.453 & 0.419 \\
\hline
\end{tabular}




\section{Conclusions}

This study investigates the concentrations and the partitioning characteristic of PAHs in the water and sediment; evaluates the relationship of sediment characteristics with $\mathrm{K}_{\mathrm{d}}$ of PAHs in the water and sediment of Nansi Lake. The results indicate that only $\mathrm{K}_{\mathrm{d}}$ values of InP and Ace are positively correlated with TOC, the $\mathrm{K}_{\mathrm{d}}$ of most PAHs was negligible correlated with TOC, soluble salt, clay and $\mathrm{pH}$ of the sediment in Nansi Lake.

\section{Acknowledgments}

This research was supported by the Science and Technology Development Project of Shandong Province (No. 2011YD10011) and the Science and Technology Project of Shandong Province (No. J17KB070).

\section{References}

1. Zhang GZ, Pan ZK, Wang XM, Mo XJ, Li XM Distribution and Accumulation of Polycyclic Aromatic Hydrocarbons (PAHs) in Food Web of Nansi Lake, China. Environ Monit Assess, 187:173(2015)

2. Liu J, Cui ZJ. Song XJ, Chen SF, Xu N, Lu F Influences of soil characteristics on the PCBS distribution in soil of the modern Yellow River delta. Ecology and Environmental Sciences, 19(1):86-91(2010)

3. Zhang GZ, Pan ZK, Li J, Li XM The Correlation of Sediments Characteristics with Organochlorine Pesticides (OCPs) in Surface Sediments of Nansi Lake, China. Advanced Materials Research, 726-731:926-930 (2013)
4. Li HL, Gao H, Zhu C, Li GG, Yang F, Gong ZY, Lian J Spatial and temporal distribution of polycyclic aromatic hydrocarbons (PAHS) in sediments of the NansiLake, China. Environmental Monitoring and Assessment, 154:469-478(2009).

5. Liu Z, Zhang YS, Su ZZ, Zhang Y, Li TH, Yang X J Distributions, sources and trends of polycyclic aromatic hydrocarbons in surface sediment in Nansihu lake. China. Population Resource and Environment, 20(6):136-140(2010)

6. Arias AH, Spetter CV, Freije RH, Marcovecchio JE Polycyclic aromatic hydrocarbons in water, mussels (Brachidontes sp., Tagelus sp.) and fish (Odontesthes sp.) from Bahl 'a Blanca Estuary, Argentina. Estuarine Coastal and Shelf Science, 85, 67-81(2009)

7. Jiao WT, Wang TY, Khim JS, Luo W, Hu WY, Naile JE, Giesy JP, Lu YL PAHs in surface sediments from coastal and estuarine areas of the northern Bohai and Yellow Seas, China. Environmental Geochemistry and Health, 34:445-456(2012)

8. Cao YX, Cao XZ, Wang H, Wan Y, Wang SL Assessment on the distribution and partitioning of perfluorinated compounds in the water and sediment of Nansi Lake, China. Environ Monit Assess, 187: 611(2015)

9. Lan JC, Sun YC, Xiao SZ Water-Sediment Partition of Polycyclic Aromatic Hydrocarbons in Karst Underground River. Environmental Science, 36(11):4081-4087(2015).

10. Zhang J, Cai LZ, Yuan DX Distribution and sources of polynuclear aromatic hydrocarbons in Mangrove surficial sediments of Deep Bay, China. Marine Pollution Bulletin, 49(5-6): 479-486(2004) 